\title{
EKSTRAKSI ZAT WARNA DARI RUMPUT LAUT Sargassum sp.
}

\section{Ruslan*, Agrippina Wiraningtyas}

Program Studi Pendidikan Kimia, STKIP Bima

Jl. Tendean, Mande, Kota Bima, NTB, 84180 Indonesia

* Corresponding author, tel/fax: (0374)42801, email: ruslan_kim@stkipbima.ac.id

\begin{abstract}
ABSTRAK
Penelitian ini bertujuan untuk mengekstraksi zat warna dan natrium alginat dari rumput laut Sargassum sp. yang tumbuh di wilayah perairan Kabupaten Bima. Rumput laut Sargassum sp. yang digunakan pada penelitian ini diambil dari petani rumput laut di Pantai Wane Kabupaten Bima. Beberapa variasi yang digunakan pada penelitian ini diantaranya metode ekstraksi, variasi pelarut, lama ekstraksi dan uji stabilitas zat warna baik terhadap suhu maupun terhadap lama penyimpanan. Karakaterisasi hasil ekstraksi zat warna menggunakan Spektrofotometer UV-Vis. Hasil yang diperoleh bahwa rumput laut Sargassum sp. dapat dimanfaatkan sebagai sumber zat warna alam dan natrium alginat. Pengaruh metode ekstraksi zat warna diperoleh bahwa metode maserasi lebih baik digunakan dibandingkan metode refluks dan microwave. Ekstrak zat warna rumput laut Sargassum sp. sangat bergantung pada sifat kepolaran pelarut. Maserasi menggunakan pelarut air menghasilkan zat warna yang lebih pekat dibandingkan maserasi menggunakan pelarut metanol dan etanol. Kondisi optimum ekstraksi zat warna dari Sargassum sp. terhadap lama maserasi dilakukan selama 2 hari perendaman. Uji kestabilan lama simpan dan pengaruh suhu terhadap zat warna Sargassum sp. pada penelitian ini menunjukkan bahwa ekstrak zat warna stabil apabila disimpan sampai 6 hari dan mampu bertahan pada suhu $70^{\circ} \mathrm{C}$.
\end{abstract}

Kata Kunci : zat warna, rumput laut, Sargassum sp.

\section{PENDAHULUAN}

Rumput laut Sargassum sp merupakan spesies rumput laut yang dapat menghasilkan alginat. Alginat telah banyak dimanfaatkan dalam berbagai industri yaitu sebagai pengental pada industri tekstil printing, penstabil emulsi pada industri obat-obatan dan makanan (Mc Hugh, 2008). Alginat terbukti menghasilkan pengental yang kadarnya tinggi (untuk pembuatan pengental cukup digunakan 2$5 \%$, mudah masuk dalam serat mudah dihilangkan kembali, selain itu juga hasil pencelupan sangat memuaskan karena membuat warna dan gambar lebih tajam. Sebab struktur kimianya mengikat pewarna, namun lebih mudah melepaskannya pada bahan kain. Agar dapat berfungsi sebagai medium, pengental harus memenuhi beberapa persyaratan, yaitu tidak berwarna, stabil dalam penyimpanan, mempunyai daya ikat dengan zat-zat yang dicampurkan, tidak mengadakan reaksi dengan zatzat tercampur dan mudah dihilangkan kembali (Lutfinor, 2011). 
Keuntungan menggunakan alginat sebagai pengental untuk pencelupan diantaranya mudah dicuci sehingga pengental dapat dibuang seiring dengan pencucian dan tidak menyebabkan kekakuan kain. Disamping menghasilkan alginat, rumput laut Sargassum sp. juga mengandung zat warna atau pigmen yang dapat digunakan sebagai pewarna alami. Beberapa jenis pigmen yang terkandung dalam rumput laut coklat antara lain fukosantin, klorofil, karoten dan pigmen lainnya, namun fukosantin sangat dominan yang memberikan warna coklat tua hingga kuning coklat pada hasil pencelupan. Rumput laut jenis Sargassum sp. memberikan warna coklat keemasan dan hasil pengujian ketahanan luntur menunjukkan nilai baik (Eriningsih, dkk., 2014). Penggunaan zat warna alam menjadi alternatif sebagai pengganti zat warna sintetis karena zat warna alam lebih aman terhadap kesehatan dan lingkungan.

Zat warna alami memiliki potensi pasar yang tinggi sebagai komoditas unggulan produk Indonesia memasuki pasar global. Pada industri tekstil, pewarnaan menjadi bagian penting dalam proses pembuatan kain. Zat warna alami memiliki potensi pasar yang tinggi sebagai komoditas unggulan produk Indonesia memasuki pasar global. Pada industri tekstil, pewarnaan menjadi bagian penting dalam proses pembuatan kain. Zat warna yang dapat digunakan dalam proses pencelupan ada beberapa jenis, disesuaikan dengan serat/benang yang digunakan, untuk benang kapas biasa digunakan zat warna reaktif sedangkan untuk benang sutera digunakan zat warna reaktif dan zat warna asam (Hartanto, 2003).

Zat warna alami memiliki potensi pasar yang tinggi sebagai komoditas unggulan produk Indonesia memasuki pasar global. Pada industri tekstil, pewarnaan menjadi bagian penting dalam proses pembuatan kain. Zat warna yang dapat digunakan dalam proses pencelupan ada beberapa jenis, disesuaikan dengan serat/benang yang digunakan, untuk benang kapas biasa digunakan zat warna reaktif sedangkan untuk benang sutera digunakan zat warna reaktif dan zat warna asam (Hartanto, 2003).

Ekstrak zat warna rumput laut coklat merupakan jenis zat warna ionik, yaitu zat warna mordan asam. Zat warna alam dapat diperoleh dengan berbagai cara sesuai sifat dari masing-masing bahan pembawa warna. Cara ekstraksi untuk memperoleh gugus pembawa warna sangat bervariasi dan akan berpengaruh terhadap warna 
yang ditimbulkan (Pujilestari, 2014). Berbagai metode yang telah digunakan dalam ekstraksi zat warna diantaranya metode maserasi, refluks, soklet. Pada penelitian ini akan dilakukan ekstraksi zat warna dari rumput laut Sargassum sp.. Beberapa variasi yang digunakan pada penelitian ini diantaranya metode ekstraksi, variasi pelarut, lama ekstraksi dan uji stabilitas zat warna baik terhadap suhu maupun terhadap lama penyimpanan. Karakaterisasi hasil ekstraksi zat warna menggunakan Spektrofotometer UV-Vis.

\section{METODE}

\section{Alat dan Bahan}

Bahan yang digunakan dalam penelitian ini adalah : Rumput laut jenis Sargassum sp. yang diambil dari perairan Pantai Wane Bima, $\mathrm{HCl}$ p.a., etanol teknis dan aquades. Alat yang diperlukan dalam penelitian ini adalah blender, baskom, timbangan analitik, peralatan gelas, kertas saring dan spektrofotometer UV-Vis.

\section{Prosedur}

\section{Preparasi Rumput Laut Sargassum sp.}

Rumput laut Sargassum sp. dicuci dengan air sampai bersih kemudian direndam dengan $\mathrm{HCl}$ 1\% selama 2 jam dan dibilas dengan air sampai pH netral. Selanjutnya rumput laut dikeringkan dengan diangin-anginkan kemudian diblender sampai diperoleh serbuk rumput laut.

\section{Ekstraksi Zat Warna}

\section{Pengaruh Metode Ekstraksi : Maserasi}

Sebanyak 20 gram serbuk rumput laut Sargassum sp. dimasukkan kedalam gelas kimia kemudian dimaserasi dengan $50 \mathrm{~mL}$ aquades selama 2 hari. Campuran tersebut kemudian disaring dan filtrat yang diperoleh diukur absorbansinya.

\section{Metode Refluks}

Sebanyak 20 gram serbuk rumput laut Sargassum sp. dimasukkan kedalam labu bulat kemudian direfluks dengan $50 \mathrm{~mL}$ aquades selama 5 jam. Campuran tersebut kemudian didinginkan dan disaring. Filtrat yang diperoleh diukur absorbansinya. 


\section{Metode Microwave}

Sebanyak 20 gram serbuk rumput laut Sargassum sp. dimasukkan kedalam wadah kemudian dimasak dengan $50 \mathrm{~mL}$ aquades dalam microwave pada power level 90 selama 20 menit. Campuran tersebut kemudian didinginkan dan disaring. Filtrat yang diperoleh diukur absorbansinya.

\section{Pengaruh Pelarut}

Sebanyak 20 gram serbuk rumput laut Sargassum sp. dimasukkan kedalam gelas kimia kemudian dimaserasi dengan $50 \mathrm{~mL}$ aquades selama 2 hari. Campuran tersebut kemudian disaring dan filtrat yang diperoleh diukur absorbansinya. Prosedur yang dilakukan ekstraksi menggunakan pelarut metanol dan etanol.

\section{Pengaruh Lama Ekstraksi}

Sebanyak 20 gram serbuk rumput laut Sargassum sp. dimasukkan kedalam gelas kimia kemudian dimaserasi dengan $50 \mathrm{~mL}$ aquades selama 1; 2; 3; dan 4 hari. Campuran tersebut kemudian disaring dan filtrat yang diperoleh diukur absorbansinya.

\section{Uji Stabilitas Zat Warna}

\section{Pengaruh Suhu}

Sebanyak 10 gram serbuk rumput laut Sargassum sp. dimasukkan kedalam gelas kimia kemudian dimaserasi dengan $100 \mathrm{~mL}$ aqudes selama waktu optimum. Campuran tersebut kemudian disaring dan filtrat yang diperoleh selanjutnya dipanaskan pada berbagai suhu diantaranya 30; 40; 50; 60 dan $70{ }^{\circ} \mathrm{C}$. Ekstrak dari hasil pemanasan selanjutnya diukur absorbansinya.

\section{Pengaruh Waktu Simpan}

Sebanyak 10 gram serbuk rumput laut Sargassum sp. dimasukkan kedalam gelas kimia kemudian dimaserasi dengan $100 \mathrm{~mL}$ aquades selama waktu optimum. Campuran tersebut kemudian disaring dan filtrat yang diperoleh selanjutnya disimpan selama 2; 4; 6 dan 8 hari kemudian diukur absorbansinya. 


\section{HASIL DAN PEMBAHASAN}

Sebelum dilakukan ekstraksi zat warna, rumput laut Sargassum sp. dicuci terlebih dahulu menggunakan air untuk menghilangkan kotoran berupa pasir dan lumpur. Kemudian direndam dalam larutan $\mathrm{HCl} 1 \%$ untuk menghilangkan mineral logam yang menempel pada rumput laut, selanjutnya dibilas dengan air sampai netral. Rumput laut yang sudah dibersihkan kemudian dikeringkan selanjutnya diblender hingga membentuk serbuk. Pada penelitian ini, sampel rumput laut Sargassum sp. dihaluskan terlebih dahulu sebelum diekstraksi. Ekstrak zat warna yang dihasilkan diukur nilai absorbansinya menggunakan Spektrofotometer UV-Vis Genesys 10S. Pengukuran absorbansi zat warna dari rumput laut Sargassum sp. menggunakan kuvet silika pada panjang gelombang $228 \mathrm{~nm}$.

\section{Ekstraksi Zat Warna}

Ekstraksi zat warna dari rumput laut Sargassum sp. dilakukan pada berbagai metode diantaranya maserasi, refluks dan microwave. Campuran hasil ekstraksi kemudian didinginkan dan disaring. Filtrat yang diperoleh selanjutnya dipanaskan untuk menguapkan pelarut sampai terbentuk ekstrak kental. Rendemen ekstrak kental zat warna rumput laut Sargassum sp. pada berbagai metode ekstraksi seperti ditunjukkan pada gambar 1. Berdasarkan data pada gambar 1, diperoleh bahwa ekstraksi menggunakan metode maserasi menghasilkan rendemen ekstrak zat warna lebih banyak dibandingkan pada metode refluks dan microwave yaitu 26,6 \%. Selain itu metode maserasi merupakan metode yang paling ekonomis, karena tidak membutuhkan energi lebih banyaka dibandingkan metode refluks dan microwave. Ekstraksi dengan metode maserasi digunakan karena merupakan metode yang paling sederhana dan murah (Donna, dkk. 2014). Namun metode maserasi membutuhkan waktu lebih lama dibandingkan metode lainnya.

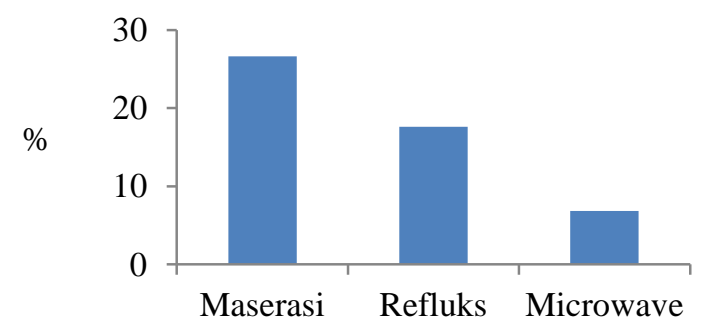

Gambar 1. Rendemen ekstrak kental zat warna pada berbagai metode ekstraksi 
Keunggulan metode maserasi dapat dibuktikan dengan data hasil pengukuran absorbansi zat warna hasil ekstraksi pada berbagai metode seperti pada tabel 1 berikut.

Tabel 1. Data Absorbansi zat warna Sargassum sp. pada variasi metode

\begin{tabular}{|l|c|}
\hline \multicolumn{1}{|c|}{ Metode Ekstraksi } & Absorbansi \\
\hline Maserasi & 3,883 \\
\hline Refluks & 3,453 \\
\hline Microwave & 3,371 \\
\hline
\end{tabular}

Berdasarkan data pada tabel 1, mateode maserasi menghasilkan zat warna dengan nilai absorbansi tertinggi, karena pada metode maserasi tidak dilakukan pemanasan. Sedangkan pada metode refluks dan microwave dilakukan pemanasan sehingga dapat mempengaruhi kestabilan zat warna. Oleh karena itu pada penelitian ini selanjutnya digunakan metode maserasi.

\section{Pengaruh Jenis Pelarut}

Ekstraksi zat warna dengan metode maserasi dilakukan pada berbagai pelarut yaitu pelarut air, metanol dan etanol. Pemilihan ketiga pelarut tersebut karena memiliki sifat kepolaran yang berbeda. Perbedaan tingkat kepolaran pelarut mengakibatkan perbedaan senyawa yang terikat pada masing-masing pelarut. Rumput laut Sargassum sp. mengandung senyawa fukosantin dan fenolik yang memiliki pigmen berwarna coklat dan bersifat polar.

Data hasil pengukuran absorbansi ekstrak zat warna rumput laut Sargassum sp. pada berbagai pelarut disajikan pada tabel 2 berikut.

Tabel 2. Data Absorbansi zat warna Sargassum sp. pada berbagai pelarut

\begin{tabular}{|l|c|}
\hline \multicolumn{1}{|c|}{ Jenis Pelarut } & Absorbansi \\
\hline Air & 3,444 \\
\hline Metanol & 3,065 \\
\hline Etanol & 2,589 \\
\hline
\end{tabular}


Berdasarkan data pada tabel 2, nilai absorbansi tertinggi dihasilkan pada maserasi menggunakan pelarut air. Hal ini membuktikan bahwa air memiliki sifat lebih polar dibandingkan dengan metanol dan etanol. Sedangkan pelarut metanol memiliki nilai absorbansi lebih tinggi dibandingkan pelarut etanol karena metanol lebih polar dibandingkan etanol. Metanol memiliki rantai karbon lebih pendek dibandingkan etanol. Berdasarkan data tersebut, maka pada penelitian ini selanjutnya akan menggunakan air sebagai pelarut untuk mengekstrak zat warna dari rumput laut Sargassum sp.. Ekstrak zat warna dari Sargassum menggunakan pelarut air merupakan senyawa florotanin yang bersifat polar dan antibakteri (Izzati, 2007). Disamping itu, pelarut air sangat mudah didapat dan murah. Menurut Prasetia (2012), air mampu melarutkan berbagai zat kimia seperti gula, garam, asam dan sebagian molekul organik. Selain itu air lebih bersifat polar dibandingkan pelarut lainnya sehingga lebih banyak zat warna polar yang dihasilkan. Ekstrak zat warna yang dihasilkan juga dipengaruhi oleh ukuran sampel yang diekstraksi. Karena menurut Prasetia (2012), bahwa ekstral Abs engaruhi oleh ukuran bahan. Bahan dengan ukuran partikel kecil memiliki luas permukaan yang labih besar sehingga kontak dan tumbukkan efektif antara pelarut dan bahan akan lebih banyak terjadi akibatnya ekstrak yang diperoleh lebih banyak dan waktu yang singkat.

\section{Pengaruh Lama Ekstraksi}

Pengaruh lama proses ekstraksi terhadap jumlah zat warna yang dihasilkan, dilakukan dengan variasi waktu maserasi yaitu 1; 2; 3 dan 4 hari. Data absorbansi zat warna hasil ekstraksi pada berbagai waktu seperti pada gambar 2 berikut.

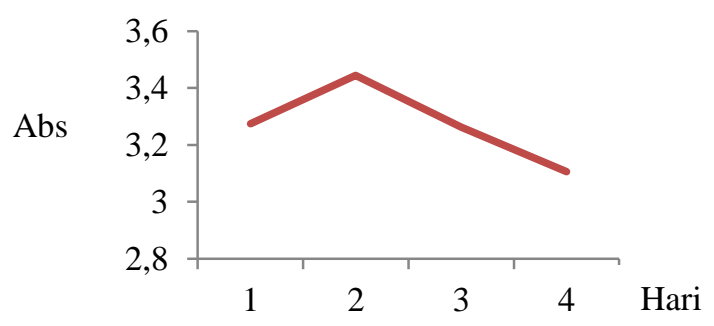

Gambar 2. Data Absorbansi zat warna pada variasi waktu maserasi 
Berdasarkan grafik pada gambar 2, data absorbansi zat warna tertinggi diperoleh pada perlakuan maserasi selama 2 hari dengan nilai absorbansi sebesar 3,444. Zat warna yang dihasilkan berwarna coklat pekat dan volume ekstrak yang dihasilkan semakin berkurang dengan semakin lamanya waktu ekstraksi. Hal ini disebabkan karena sifat swelling dari senyawa alginat dalam rumput laut Sargassum sp. yang dapat mengembang apabila dilarutkan dalam air. Molekul air yang digunakan sebagai pelarut pada proses maserasi akan diserap. Semakin lama waktu maserasi, maka semakin banyak air yang diserap sehingga jumlah molekul air sebagai pelarut zat warna semakin berkurang akibatnya ekstrak zat warna yang dihasilkan semakin sedikit.

\section{Uji Stabilitas Zat Warna}

\section{Pengaruh Suhu}

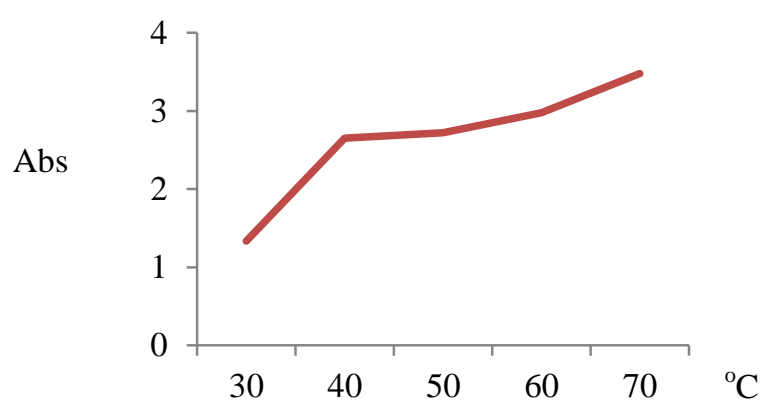

Gambar 3. Grafik absorbansi zat warna terhadap perubahan suhu

Pengaruh suhu terhadap stabilitas zat warna rumput laut Sargassum sp. dilakukan dengan memanaskan ekstrak zat warna pada berbagai suhu. Data hasil pengaruh suhu terhadap stabilitas zat warna seperti ditunjukkan pada gambar 3. Berdasarkan data tersebut bahwa semakin tinggi suhu ekstrak zat warna maka absorbansinya semakin besar. Hal ini menunjukkan bahwa pemanasan zat warna sampai suhu $70{ }^{\circ} \mathrm{C}$ tidak akan merusak zat warna.

\section{Pengaruh Lama Simpan}

Pengaruh lama simpan terhadap stabilitas zat warna rumput laut Sargassum sp. dilakukan dengan menyimpan ekstrak zat warna selama beberapa hari. Data hasil 
pengaruh lama simpan terhadap stabilitas zat warna seperti ditunjukkan pada gambar 4 berikut.

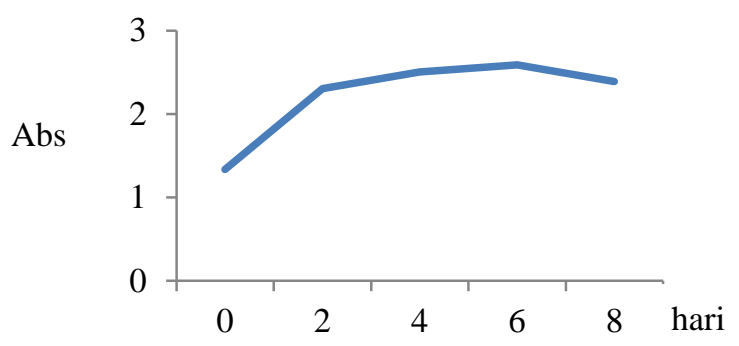

Gambar 4. Grafik absorbansi zat warna terhadap lama simpan

Berdasarkan data tersebut bahwa semakin lama masa simpan maka kestabilannya meningkat pada penyimpanan selama 6 hari, namun pada penyimpanan 8 hari mengalami penurunan nilai absorbansi.

\section{KESIMPULAN}

Berdasarkan hasil penelitian dapat disimpulkan bahwa rumput laut Sargassum sp. dapat dimanfaatkan sebagai sumber zat warna alam dan natrium alginat. Ekstraksi zat warna dari rumput laut Sargassum sp. lebih baik menggunakan metode maserasi dibandingkan metode refluks dan microwave. Ekstrak zat warna rumput laut Sargassum sp. sangat bergantung pada sifat kepolaran pelarut. Maserasi menggunakan pelarut air menghasilkan zat warna yang lebih pekat dibandingkan maserasi menggunakan pelarut metanol dan etanol. Kondisi optimum ekstraksi zat warna dari rumput laut Sargassum sp. terhadap lama maserasi dilakukan selama 2 hari perendaman. Uji kestabilan lama simpan dan pengaruh suhu terhadap zat warna rumput laut Sargassum sp. menunjukkan bahwa ekstrak dapat stabil apabila disimpan sampai 6 hari dan mampu bertahan pada suhu $70{ }^{\circ} \mathrm{C}$.

\section{UCAPAN TERIMAKASIH}

Penulis mengucapkan terimakasih kepada Direktorat Riset dan Pengabdian kepada Masyarakat Direktorat Jenderal Penguatan Riset dan Pengembangan Kementerian Riset, Teknologi dan Pendidikan Tinggi Republik Indonesia yang telah mendanai penelitian ini melalui skim Penelitian Dosen Pemula tahun 2017. 


\section{DAFTAR PUSTAKA}

Amir, A., Wiraningtyas, A., Ruslan, Annafi, N. 2016. Perbandingan Metode Ekstraksi Natrium Alginat: Metode Konvensional dan MAE. Chempublish Journal. 1 (2): 7-11.

Donna, D. Damanik, P. Surbakti, N. Hasibuan, R. 2014. Ekstrak Katekin Dari Daun Gambir (Uncaria gambir roxb) dengan Metode Maserasi.

Eriningsih, R., Marlina, R., Mutia, T., Wibisana, A., Titis, A. 2014. Eksplorasi Kandungan Pigmen dan Alginat dari Rumput Laut Coklat untuk Proses Pewarnaan Kain Sutera. Arena Tekstil, 29 (2): 73-80.

Hartanto, N.S., Watanabe, S. 2003. Teknologi Tekstil. Pradnya Paramita. Jakarta.

Izzati, M. 2007. Skreening Potensi Antibakteri Spesies Rumput Laut terhadap Bakteri Patogen pada Udang Windu. Jurnal Bioma. 9 (2); 62-67.

Jain, T., Jain, V., Pandey, R., Vyas, A., \& Shukla, S. 2009. Microwave Assisted Extraction for Phytoconstituents - An Overvie. Asian J. Research Chem. 2 (1): $19-25$.

Lutfinor. 2011. Penggunaan Bentonit sebagai Pengental dalam Proses Pewarnaan Kain Tenun Palembang. Jurnal Dinamika Penelitian Industri. 22 (1): 41-47.

Prasetia, D. 2012. Pengambilan Zat Warna Alami dari Kayu Nangka. Jurnal Teknologi Kimia dan Industri. 1 (1): 502-507.

Pujilestari, T. 2014. Pengaruh Ekstraksi Zat Warna Alam dan Fiksasi Terhadap Ketahanan Luntur Warna pada Kain Batik Katun. Dinamika Kerajinan dan Batik. 31 (1): 7-9.

Subaryono. 2011. Potensi dan peluang pemanfaatan rumput laut coklat di Indonesia. Squalen. 6 (2).

Tjitrosoepomo, G. 2001. Taksonomi Tumbuhan: Schizophyta, Thallophyta, Bryophyta dan Pteridophyta, Gadjah Mada University Press. Yogyakarta. 